\title{
Serum positive thyroglobulin antibodies: an old problem with new questions
}

Fernanda Vaisman'

\section{INTRODUCTION}

S erum thyroglobulin ( $\mathrm{Tg})$ is a cornerstone on the follow up of differentiated $\checkmark$ thyroid cancer (DTC) and is widely used for diagnostic and prognostic purposes (1). Some factors might interfere in the measurement, being the most common the presence of thyroglobulin antibodies $(\mathrm{TgAB})(2)$. This is known to happen in nearly one third of patients. In this scenario, image modalities become even more important during follow up as serum $\mathrm{Tg}$ measurement in not reliable and $\mathrm{TgAB}$ absolute values and/or TgAB's curve over time is not as accurate. Furthermore, it is also known that lymph node metastasis can be found in more than $50 \%$ of patients at diagnosis and it is the most common site of persistence/recurrence of disease (1). The appropriate initial surgical procedure can lower the frequency of persistence/recurrence of lymph node metastatic disease.

In addition to a well-performed neck ultrasound, the ultrasound guided fine needle aspiration biopsy (FNAB) should be performed in every suspicious lymph node in order to confirm malignancy. As these biopsies still carry up to $10 \%$ of false negative results (3) recommended to measure $\mathrm{Tg}$ levels in needle washouts (Tg-FNAB). Therefore, another issue came up during the last couple of years: does the presence of serum $\mathrm{TgAB}$ interfere with the measurement of $\mathrm{Tg}-\mathrm{FNAB}$ as they are present also in the washouts?

\section{METHODS}

Martins-Costa and cols. (4), assessed 232 FNAB samples obtained from suspicious lymph neck nodes from 144 DTC patients. Regular cytology, Tg-FNAB, TgAB in the washouts and also serum $\mathrm{Tg}$ and $\mathrm{TgAB}$ were performed in all patients. They have used the literature-validated cutoffs. Tg-FNAB was performed using a commercially available assay with functional sensitivity of $1.0 \mathrm{ng} / \mathrm{mL}$ and if $\mathrm{Tg}-\mathrm{FNAB}$ was lower than 10 $\mathrm{ng} / \mathrm{mL}$ and patient had serum $\mathrm{Tg} \mathrm{AB}$ positivity, another assay with lower sensitivity was used to exclude contamination by $\mathrm{TgAB}$.

\section{RESULTS}

Patients were divided into two groups: group 1 (203 FNAB samples): serum negative $\mathrm{TgAB}$ and group 2 (29 FNAB samples): serum positive $\mathrm{TgAB}$. In the first group, all patients with $\mathrm{Tg}-\mathrm{FNAB}>10 \mathrm{ng} / \mathrm{mL}$ had metastatic disease confirm by histology or ${ }^{\mathrm{Il} 3} \mathrm{l}$ uptake, however, only $57 \%$ had positive cytology. When Tg-FNAB was $<10 \mathrm{ng} / \mathrm{mL}$, only $10 \%$ had confirm metastatic disease and FNAB was able to

${ }^{1}$ Instituto Nacional de Câncer (Inca). Programa de

Pós-Graduação Stricto-Sensu em Endocrinologia, Universidade Federal do Rio de Janeiro (UFRJ), Rio de Janeiro, RJ, Brasil

Correspondence to: Fernanda Vaisman fevaisman@globo.com

Received on Mar/23/2017 Accepted on Mar/23/2017 DOI: 10.1590/2359-3997000000263 
identify only $2 \%$. In group 2 , when $\mathrm{Tg}$-FNAB was above $10 \mathrm{ng} / \mathrm{mL}$, also all patients had confirmed metastatic disease and positive cytology but when less than 10 $\mathrm{ng} / \mathrm{mL}$, around $45 \%$ had confirmed metastatic disease by histology or ${ }^{113} 1$ uptake but only $25 \%$ had positive cytology. In both groups there were a high frequency of non-diagnostic cytology FNABs when Tg-FNAB was less than $10 \mathrm{ng} / \mathrm{mL}$, showing that neither $\mathrm{Tg}-\mathrm{FNAB}$ nor cytology were able to identify those cases of lymph node metastasis.

\section{COMMENTS}

The authors nicely showed that $\mathrm{Tg}$-FNAB is a useful tool to diagnose lymph node metastasis as they proved that, when above $10 \mathrm{ng} / \mathrm{mL}$, all patients had confirmed metastatic disease, independently on the $\mathrm{Tg}-\mathrm{AB}$ serum status. Thus, if $\mathrm{Tg}-\mathrm{FNAB}$ is high in a suspicious lymph node, is likely that will be confirmed as metastatic disease. Interestingly, Tg-FNAB was even more accurate than cytology. That information reinforces the recommendation that $\mathrm{Tg}$-FNAB should be measured when suspicious lymph nodes are biopsied in order to increase sensitivity.

Conversely, when $\mathrm{Tg}$-FNAB was lower, the accuracy was not as good but neither was cytology.

Even more important, in the present study, the authors also showed that the same phenomenon occurs in serum $\operatorname{TgAB}$ positive and negative patients, suggesting that the presence of $\mathrm{TgAB}$ in the serum does not interfere significantly in $\mathrm{Tg}$-FNAB measurement. This is an ongoing discussion in the literature. Shin and cols., studied 239 lymph nodes from 201 PTC patients and found that the presence of serum $\mathrm{TgAB}$ in fact interfered with $\mathrm{Tg}$-FNAB measurement (5) and similarly, Jo and cols. suggested that serum $\mathrm{TgAB}$ might lower Tg-FNAB. This last study proposed to lower the Tg-FNAB cutoff for serum $\mathrm{TgAb}$ positive patients (6). However, those studies performed FNAB of suspicious lymph nodes before thyroid surgery when serum $\mathrm{TgAB}$ levels were higher than in Martins-Costa's and cols. study. Therefore, the interference of serum $\mathrm{TgAB}$ in $\mathrm{Tg}-\mathrm{FNAB}$ measurement might be significant when serum $\mathrm{TgAB}$ are higher and differences in cutoffs for both measurements should be considered in those situations.

Disclosure: no potential conflict of interest relevant to this article was reported.

\section{REFERENCES}

1. Haugen BR, Alexander EK, Bible KC, Doherty GM, Mandel SJ, Nikiforov YE, et al. 2015 American Thyroid Association Management Guidelines for Adult Patients with Thyroid Nodules and Differentiated Thyroid Cancer: The American Thyroid Association Guidelines Task Force on Thyroid Nodules and Differentiated Thyroid Cancer. Thyroid. 2016;26(1):1-133.

2. Spencer C, Petrovic I, Fatemi S, LoPresti J. Serum thyroglobulin ( $\mathrm{Tg}$ ) monitoring of patients with differentiated thyroid cancer using sensitive (second-generation) immunometric assays can be disrupted by false-negative and false-positive serum thyroglobulin autoantibody misclassifications. J Clin Endocrinol Metab. 2014;99(12):4589-99.

3. Ahuja AT, Chow L, Chick W, King W, Metreweli C. Metastatic cervical nodes in papillary carcinoma of the thyroid: ultrasound and histological correlation. Clin Radiol. 1995;50(4):229-31.

4. Martins-Costa MC, Maciel RMB, Kasamatsu TS, Nakabashi CCD, Camacho CP, Crispim F, et al. Clinical impact of thyroglobulin ( $\mathrm{Tg})$ and $\mathrm{Tg}$ autoantibody (TgAb) measurements in needle washouts of neck lymph node biopsies with papillary thyroid carcinoma. Arch Endocrinol Metab. 2017;61(2):108-14.

5. Shin HJ, Lee HS, Kim EK, Moon HJ, Lee JH, Kwak JY. A Study on Serum Antithyroglobulin Antibodies Interference in Thyroglobulin Measurement in Fine-Needle Aspiration for Diagnosing Lymph Node Metastasis in Postoperative Patients. PLoS One. 2015;10(6):e0131096.

6. Jo K, Kim MH, Lim Y, Jung SL, Bae JS, Jung CK, et al. Lowered cutoff of lymph node fine-needle aspiration thyroglobulin in thyroid cancer patients with serum anti-thyroglobulin antibody. Eur J Endocrinol. 2015;173(4):489-97. 